\title{
Economic Analysis on Petroleum Consumption Zhang-huang $\mathrm{YE}^{1,2}$, Qiang YAN ${ }^{2}$ and Xiao-jing $\mathrm{CHEN}^{2}$
}

1.Jiangxi Science and Technology Normal University, Nanchang, Jiangxi; 2.Institute of Mineral Resources, Chinese Academy of Geological Sciences, Beijing;

Corresponding author at chuckverna@sina.com

Keywords: Petroleum, price, consumption proportion, foreign dependence degree, economic growth

Abstract. With the real GDP growth of the world's three largest economies-China, USA and Japan as dependent variables while international petroleum price growth, proportion of petroleum consumption and dependence on foreign petroleum as independent variables, this paper will probe into the relationship between dependent variables and independent variables based on the econometric model. Upon the analysis, it shows that rising international oil price and heavy dependence on petroleum consumption exert a negative influence on China's GDP, but they have little effect or even a positive effect on USA's GDP and Japan's GDP, which illustrates that USA and Japan have been well rewarded by their investment and exploration of overseas petroleum resources for many years.

Petroleum occupies one third of the global primary energy supply and is the world's largest energy. In terms of the supply and demand pattern, the world petroleum market pattern characterized by the separation of demand and supply sides has been formed while western countries control the global petroleum supply and developing countries become main demand-sides. The petroleum price fluctuation will threaten China’s energy security.

\section{Analysis and Processing of Variables in Econometric Model}

In the last 45 years, China's real GDP growth rate was 0.091 while USA's real GDP growth rate being 0.029 and Japan 0.037. Over the past 45 years, especially since 1980, China's GDP has been in pretty high and relatively stable growth. USA's real GDP growth was also relatively stable for the past 39 years. And Japan's real GDP growth was comparatively stable for the last 45 years. But it can be observed that Japan's real GDP growth is in a slow downward trend when compared with that of USA and China (Fig. 1). According to the stationary test on the real GDP growth of the three countries, the real GDP of China, USA and Japan is in stable growth.

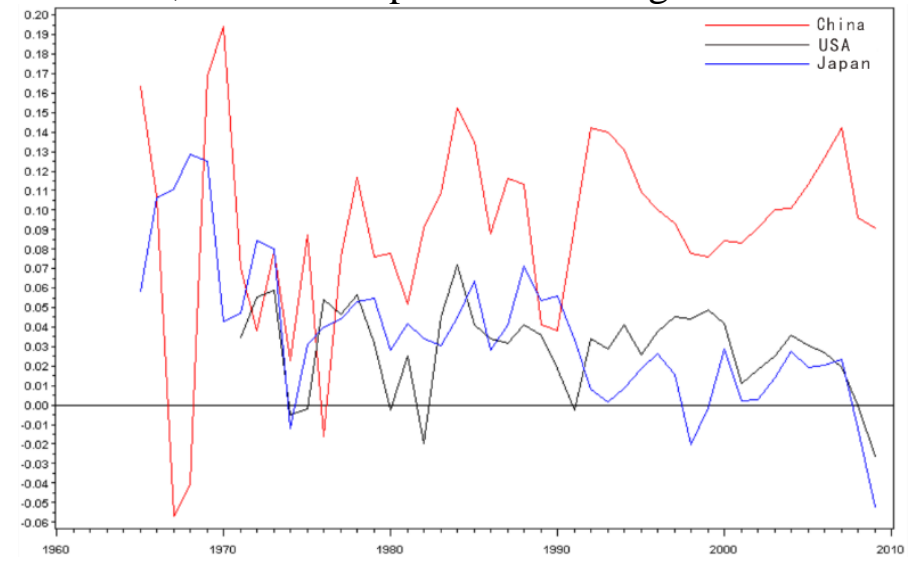

Fig. 1 The Real GDP Growth of China, USA and Japan

In the last 45 years, China's proportion of petroleum consumption was 0.179 while USA's proportion of petroleum consumption being 0.416 and Japan 0.594 . Over the past 45 years, especially since 1980, China has kept a relatively stable proportion of oil consumption. USA had a relatively stable proportion of petroleum consumption but its proportion was in a slow downward 
trend for the past 45 years. Compared with that of USA and China, Japan's proportion of petroleum consumption has been in a large declining trend ever since 1980. Up to 2009, Japan's proportion of petroleum consumption was very nearly the same as USA's (Fig.2). In the light of the stationary test on the proportion of petroleum consumption of the three countries, the proportion of petroleum consumption of China, USA and Japan is all in a non-stationary tendency.

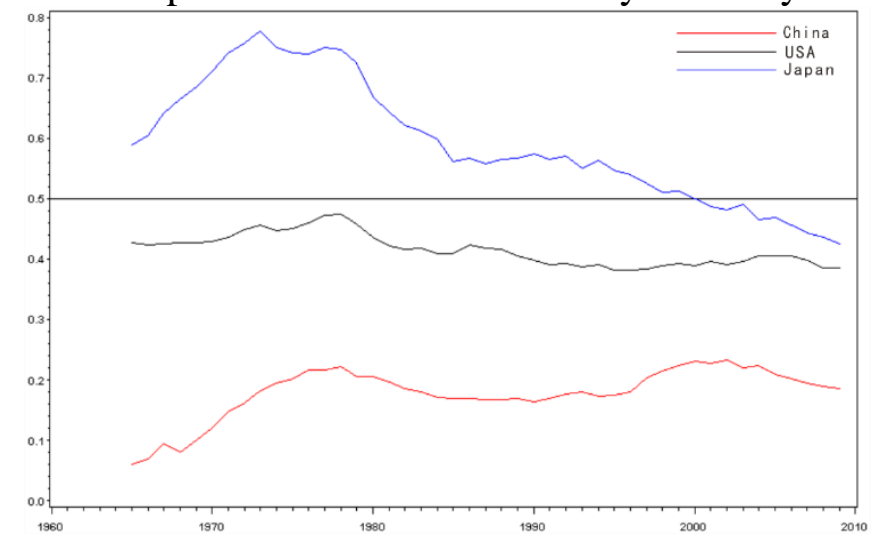

Fig. 2 Proportion of Petroleum Consumption of China, USA and Japan

As for dependence on foreign petroleum, over the past 45 years, China's degree of dependence on foreign petroleum was -0.001 while USA 0.422 and Japan 0.997 . In the last 45 years, there are two crucial points of time related to the change of dependence on foreign petroleum: before 1985, China was a net exporter of petroleum and its exports peaked in 1985; after 1985, degree of dependence on foreign petroleum kept increasing. By 1993, China has become a net importer and its degree of dependence upon import has been increasing year by year. By the end of 2008, China's degree of dependence on foreign petroleum was 0.465. USA's degree of dependence on foreign petroleum was in a slow upward trend for the past 45 years, reaching a maximum of 0.6529 in 2005. Japan's degree of dependence on foreign petroleum was more than 0.99 and changed little for the past 45 years (Fig.3). In line with the stationary test on dependence on foreign petroleum, results show that China's dependence on foreign petroleum is in non-stationary growth and it is the same case with USA, while Japan's dependence on foreign petroleum is in stationary trend.

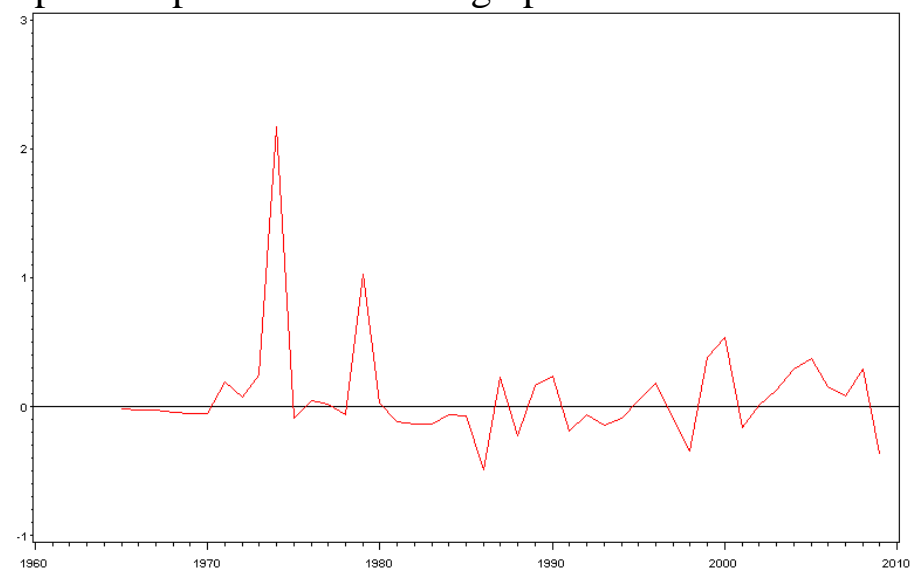

Fig. 3 Dependence on Foreign Petroleum of China, USA and Japan

In recent 45 years, the average international petroleum price growth was 0.086 with the minimum being -0.486 and maximum 2.173 (diagram 4). The steadiness of data series is proved by the stationary test on international petroleum price growth. 


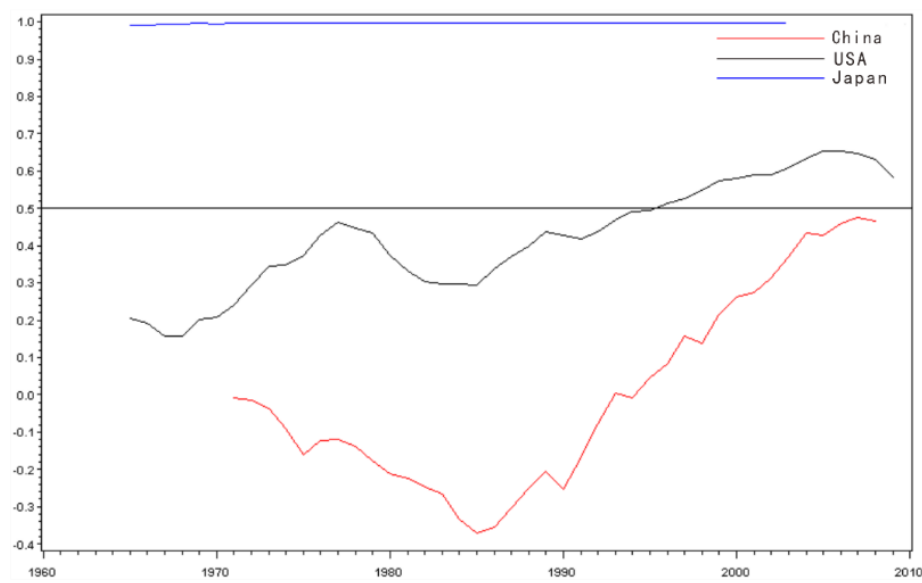

Fig. 4 International Petroleum Price Growth

It can be seen from table 1 that there exists missing data of these two indicators including USA's real GDP growth and China's dependence on imported petroleum, respectively missing data for six and seven years. Whereas, data of other indicators from 1965 to 2009 are intact.

Data series of the three countries are non-stationary in terms of proportion of petroleum consumption, thus the steadiness can be realized by calculating growth rate. Likewise, because data series of USA and China are non-stationary for dependence on foreign petroleum, the steadiness can also be achieved in this way. By contrast, there is no need to do calculating for the stationary data series of Japan for dependence on foreign petroleum. After calculating growth rates respectively, growth rates are demonstrated to be stable upon the stationary test.

Then, multivariate regression model can be established to verify how real GDP growth is affected by international petroleum price growth, proportion of petroleum consumption and dependence on foreign petroleum.

Table 1 Descriptive Statistics of Variables

\begin{tabular}{|c|c|c|c|c|c|}
\hline Variables & $\mathrm{N}$ & Average & $\begin{array}{l}\text { Standard } \\
\text { Error } \\
\end{array}$ & Minimum & Maximum \\
\hline China's real GDP annual growth rate & 45 & 0.091 & 0.050 & -0.057 & 0.194 \\
\hline USA's real GDP annual growth rate & 39 & 0.029 & 0.022 & -0.026 & 0.072 \\
\hline Japan's real GDP annual growth rate & 45 & 0.037 & 0.037 & -0.052 & 0.129 \\
\hline $\begin{array}{l}\text { International petroleum price growth } \\
\text { (in real terms) }\end{array}$ & 45 & 0.086 & 0.406 & -0.486 & 2.173 \\
\hline $\begin{array}{l}\text { China's proportion of petroleum } \\
\text { consumption }\end{array}$ & 45 & 0.179 & 0.042 & 0.060 & 0.234 \\
\hline USA's proportion of petroleum consumption & 45 & 0.416 & 0.026 & 0.382 & 0.475 \\
\hline $\begin{array}{l}\text { Japan's proportion of petroleum } \\
\text { consumption }\end{array}$ & 45 & 0.594 & 0.102 & 0.426 & 0.779 \\
\hline $\begin{array}{c}\text { China's degree of dependence on foreign } \\
\text { petroleum }\end{array}$ & 38 & -0.001 & 0.261 & -0.370 & 0.475 \\
\hline $\begin{array}{l}\text { USA's degree of dependence on foreign } \\
\text { petroleum }\end{array}$ & 45 & 0.422 & 0.146 & 0.156 & 0.653 \\
\hline $\begin{array}{c}\text { Japan's degree of dependence on foreign } \\
\text { petroleum }\end{array}$ & 45 & 0.997 & 0.001 & 0.992 & 0.998 \\
\hline
\end{tabular}

\section{Influence on China}

Calculation model: $\mathrm{Y}=\mathrm{a} 1+\mathrm{a} 2 * \mathrm{X} 1+\mathrm{a} 3 * \mathrm{X} 2+\mathrm{a} 4 * \mathrm{X} 3+\mathrm{e}$

$\mathrm{X} 1$ is international petroleum price growth, $\mathrm{X} 2$ is growth rate of proportion of petroleum consumption, $\mathrm{X} 3$ is growth rate of dependence on foreign petroleum, e is residual error, a1-a3 denotes parameter estimates.

The model is significant under the significance level of 0.05 but not significant under the significance level of 0.01 . And R2 of the whole model after modulation is 0.1750 (table 2). 
Table 2 China-Significance of the Model (enter)

\begin{tabular}{|c|r|r|r|r|r|}
\hline \multicolumn{7}{|c|}{ Analysis of Variance } \\
\hline Source & \multicolumn{1}{|c|}{ DF } & \multicolumn{1}{c|}{$\begin{array}{c}\text { Sum of } \\
\text { Squares }\end{array}$} & $\begin{array}{c}\text { Mean } \\
\text { Square }\end{array}$ & F Value & Pr \\
\hline Model & 3 & 0.0113 & 0.00377 & 3.55 & 0.0249 \\
\hline Error & 33 & 0.03506 & 0.00106 & & \\
\hline Corrected Total & 36 & 0.04636 & & & \\
\hline
\end{tabular}

Under the significance level of 0.05 , international petroleum price growth, growth rate of proportion of petroleum consumption and growth rate of dependence on foreign petroleum have no remarkable effect on real GDP growth. But under the significance level of 0.1 , real GDP growth is influenced significantly by international petroleum price growth and growth rate of proportion of petroleum consumption (table 3).

Table 3 China-Model Parameter Estimates (enter)

\begin{tabular}{|c|c|r|r|r|r|}
\hline \multicolumn{7}{|c|}{ Parameter Estimates } \\
\hline Variable & DF & $\begin{array}{c}\text { Parameter } \\
\text { Estimate }\end{array}$ & $\begin{array}{c}\text { Standard } \\
\text { Error }\end{array}$ & t Value & $\operatorname{Pr}|\mathrm{t}|$ \\
\hline Intercept & 1 & 0.09605 & 0.00567 & 16.94 & $<.0001$ \\
\hline X1 & 1 & -0.02463 & 0.0128 & -1.92 & 0.0629 \\
\hline X2 & 1 & -0.2247 & 0.11116 & -2.02 & 0.0514 \\
\hline X3 & 1 & -0.00312 & 0.00453 & -0.69 & 0.4961 \\
\hline
\end{tabular}

After screening through stepwise method, international petroleum price growth and growth rate of proportion of petroleum consumption are selected into the model. And these two variables have a significant influence on real GDP growth (table 4). R2 of the whole model after modulation is 0.2923 .

Table 4 China-Significance of the Model (stepwise)

\begin{tabular}{|c|r|r|r|r|r|}
\hline \multicolumn{7}{|c|}{ Analysis of Variance } \\
\hline Source & DF & \multicolumn{1}{c|}{$\begin{array}{c}\text { Sum of } \\
\text { Squares }\end{array}$} & $\begin{array}{c}\text { Mean } \\
\text { Square }\end{array}$ & & \\
\hline Model & 2 & 0.0108 & 0.0054 & 5.16 & 0.011 \\
\hline Error & 34 & 0.03556 & 0.00105 & & \\
\hline $\begin{array}{c}\text { Corrected } \\
\text { Total }\end{array}$ & 36 & 0.04636 & & & \\
\hline
\end{tabular}

Parameter estimate of international petroleum price growth is -0.02673 , which means that international petroleum price growth has negative relation with real GDP growth. Real GDP growth will decrease by 0.02673 units while international petroleum price growth increases per unit. Parameter estimate of growth rate of proportion of petroleum consumption is -0.24132 , that is, there exists a negative correlation between growth rate of proportion of petroleum consumption and real GDP growth. Real GDP growth will decrease by 0.24132 units with each unit increase in growth rate of proportion of petroleum consumption (table 5).

Table 5 China-Model Parameter Estimates (stepwise)

\begin{tabular}{|c|c|c|c|c|c|}
\hline & Parameter & Standard & Type II SS & F Value & $\operatorname{Pr}>$ F \\
\cline { 2 - 4 } & Estimate & Error & & & \\
\hline Intercept & 0.09666 & 0.00556 & 0.31645 & 302.56 & $<.0001$ \\
\hline X1 & -0.02673 & 0.01233 & 0.00492 & 4.7 & 0.0373 \\
\hline X2 & -0.24132 & 0.10766 & 0.00526 & 5.02 & 0.0316 \\
\hline
\end{tabular}




\section{Influence on USA}

Model: $\mathrm{Y}=\mathrm{a} 1+\mathrm{a} 2 * \mathrm{X} 1+\mathrm{a} 3 * \mathrm{X} 2+\mathrm{a} 4 * \mathrm{X} 3+\mathrm{e}$

$\mathrm{X} 1$ is international petroleum price growth, $\mathrm{X} 2$ is growth rate of proportion of petroleum consumption, $\mathrm{X} 3$ is growth rate of dependence on foreign petroleum.

The model is significant under the significance level of 0.05 and R2 of the whole model after modulation is 0.2299 (table 6).

Table 6 USA-Significance of the Model (enter)

\begin{tabular}{|c|r|r|r|r|r|}
\hline \multicolumn{7}{|c|}{ Analysis of Variance } \\
\hline Source & DF & Sum of & Mean & \multirow{2}{*}{ F Value } & \multirow{2}{*}{ Pr F } \\
\cline { 3 - 4 } & & Squares & Square & & \\
\hline Model & 3 & 0.00443 & 0.00148 & 4.58 & 0.0086 \\
\hline Error & 33 & 0.01063 & 0.0003222 & & \\
\hline Corrected Total & 36 & 0.01506 & & & \\
\hline
\end{tabular}

Under the significance level of 0.05 , dependence on foreign petroleum has a notable effect on real GDP growth while international petroleum price growth and growth rate of proportion of petroleum consumption have no significant impact on real GDP growth (table 7).

Table 7 USA-Model Parameter Estimates (enter)

\begin{tabular}{|c|c|r|r|r|r|}
\hline \multicolumn{7}{|c|}{ Parameter Estimates } \\
\hline Variable & DF & Parameter & Standard & t Value & $\operatorname{Pr}>|t|$ \\
\cline { 3 - 4 } & & Estimate & \multicolumn{1}{|c|}{ Error } & & \\
\hline Intercept & 1 & 0.02795 & 0.00363 & 7.7 & $<.0001$ \\
\hline $\mathrm{X} 1$ & 1 & -0.00628 & 0.00717 & -0.88 & 0.3873 \\
\hline $\mathrm{X} 2$ & 1 & 0.09467 & 0.21095 & 0.45 & 0.6565 \\
\hline $\mathrm{X} 3$ & 1 & 0.12231 & 0.05526 & 2.21 & 0.0339 \\
\hline
\end{tabular}

After screening through stepwise method, growth rate of dependence on foreign petroleum is elected into the model. This variable has an obvious effect on real GDP growth (table 8), and R2 of the whole model after modulation is 0.2660 .

Table 8 USA-Significance of the Model (stepwise)

\begin{tabular}{|r|r|r|r|r|r|}
\hline \multicolumn{7}{|c|}{ Analysis of Variance } \\
\hline Source & \multirow{2}{*}{ DF } & Sum of & Mean & F Value & Pr $>$ F \\
\cline { 3 - 5 } & & Squares & Square & & \\
\hline Model & 1 & 0.00401 & 0.00401 & 12.68 & 0.0011 \\
\hline Error & 35 & 0.01106 & 0.0003159 & & \\
\hline Corrected Total & 36 & 0.01506 & & & \\
& & & & & \\
\hline
\end{tabular}

Parameter estimate of growth rate of dependence on foreign petroleum is 0.14255 , which implies that real GDP growth is positively correlated to growth rate of dependence on foreign petroleum. Real GDP growth will increase by 0.14255 units with each unit increase in growth rate of dependence on foreign petroleum (table 9).

Table 9 USA-Model Parameter Estimates (stepwise)

\begin{tabular}{|r|r|r|r|r|r|}
\hline Variable & Parameter & Standard & Type II SS & F Value & Pr $>$ F \\
\cline { 2 - 4 } & Estimate & Error & & & \\
\hline Intercept & 0.02634 & 0.00315 & 0.02212 & 70.03 & $<.0001$ \\
\hline X3 & 0.14255 & 0.04003 & 0.00401 & 12.68 & 0.0011 \\
\hline
\end{tabular}

\section{Influence on Japan}

Model: $\mathrm{Y}=\mathrm{a} 1+\mathrm{a} 2 * \mathrm{X} 1+\mathrm{a} 3 * \mathrm{X} 2+\mathrm{a} 4 * \mathrm{X} 3+\mathrm{e}$

$\mathrm{X} 1$ is international petroleum price growth, $\mathrm{X} 2$ is growth rate of proportion of petroleum consumption, $\mathrm{X} 3$ is dependence on foreign petroleum. 
The model is not significant under the significance level of 0.05 , and R2 of the whole model after modulation is 0.0394 (table 10).

Table 10 Japan-Significance of the Model (enter)

\begin{tabular}{|r|r|r|r|r|r|}
\hline \multicolumn{7}{|c|}{ Analysis of Variance } \\
\hline Source & \multirow{2}{*}{ DF } & Sum of & Mean & F Value & Pr $>$ F \\
\cline { 3 - 5 } & & Squares & Square & & \\
\hline Model & 3 & 0.0027 & 0.0009012 & 1.49 & 0.2349 \\
\hline Error & 33 & 0.01994 & 0.0006042 & & \\
\hline Corrected Total & 36 & 0.02264 & & & \\
& & & & & \\
\hline
\end{tabular}

After screening through stepwise method, there is no significant variable into the model, which manifests that X1, X2 and X3 all have no significant effect on real GDP growth.

\section{Conclusion}

For China, international petroleum price growth has a negative relation with real GDP growth: when international petroleum price growth increases per unit, real GDP growth will decrease by 0.02673 units. And there is a negative correlation between growth rate of proportion of petroleum consumption and real GDP growth: when growth rate of proportion of petroleum consumption increases per unit, real GDP growth will decrease by 0.24132 units. However, growth rate of dependence on foreign petroleum has no significant effect on real GDP growth.

For USA, international petroleum price growth and growth rate of proportion of petroleum consumption have no remarkable influence on real GDP growth. Growth rate of dependence on foreign petroleum is positively correlated to real GDP growth: when growth rate of dependence on foreign petroleum increases per unit, real GDP growth will increase by 0.14255 units.

For Japan, international petroleum price growth, growth rate of proportion of petroleum consumption and dependence on foreign petroleum all have no significant impact on real GDP growth.

In general, high petroleum price growth rate (or high petroleum price), greater proportion of petroleum consumption as well as increasing dependence on foreign petroleum are likely to have an adverse impact on the economy. It can be concluded from the above analysis that the rising price of international petroleum and heavy dependence on imported petroleum both have a passive influence on China's GDP but have little impact or even a positive effect on GDP of USA and Japan, which demonstrates that the investment and exploration of overseas petroleum resources for many years has brought profitable returns to USA and Japan.

\section{References}

[1]. Hans-Holger Rogner. 1999. Sustainable Energy Development-Economics and Externalities[J]. the Scientifie Forum of 43rd General Conference of the International Atomic Energy Ageney, Vienna, September 28-29.

[2]. IEA. 2012. World Energy Outlook 2012[R]. Paris: International Energy Agency.

[3]. Markandya A, Boyd R. 2000. Economic evaluation of environmental impacts and external costs[R]. UK, Bath: Metroeconomica Consultant, Ltd.

[4]. Ke Jinchuan, Hao Yi. 2008. A Coordination Study on Economic Development and Energy Industrial Policy[J]. Economic Survey, (4): 28-31.

[5]. Wang An-jian, Wang Gaoshang, etc. 2008. Energy and National Economic Development[M]. Beijing: Geological Publishing House. 